\title{
Corrigendum: Comparative Analysis of G1P[8] Rotaviruses Identified Prior to Vaccine Implementation in Pakistan With Rotarix ${ }^{\mathrm{TM}}$ and RotaTeq ${ }^{\text {TM }}$ Vaccine Strains
}

\section{OPEN ACCESS}

Approved by:

Frontiers Editorial Office, Frontiers

Media SA, Switzerland

*Correspondence: Nazish Bostan

nazishbostan@comsats.edu.pk

Specialty section: This article was submitted to Vaccines and Molecular Therapeutics,

a section of the journal

Frontiers in Immunology

Received: 02 November 2020 Accepted: 16 November 2020

Published: 16 December 2020

Citation:

Sadiq A and Bostan N (2020) Corrigendum: Comparative Analysis of G1P[8] Rotaviruses Identified Prior to Vaccine Implementation in

Pakistan With Rotarix ${ }^{\mathrm{TM}}$ and RotaTeq ${ }^{\mathrm{TM}}$ Vaccine Strains.

Front. Immunol. 11:625157. doi: 10.3389/fimmu.2020.625157

\section{Asma Sadiq and Nazish Bostan *}

Department of Biosciences, COMSATS University (CUI), Islamabad, Pakistan

Keywords: G1P[8], rotavirus, genotype, antigenic epitopes, emergence

\section{A Corrigendum on}

Comparative Analysis of G1P[8] Rotaviruses Identified Prior to Vaccine Implementation in Pakistan With Rotarix ${ }^{\mathrm{TM}}$ and RotaTeq ${ }^{\mathrm{TM}}$ Vaccine Strains

By Sadiq A and Bostan N (2020). Front. Immunol. 11:562282. doi: 10.3389/fimmu.2020.562282

In the original article, there was an error in the correspondence section. The only corresponding author is Nazish Bostan, nazishbostan@comsats.edu.pk. A correction has therefore been made to the correspondence section and should read as follows:

${ }^{\star}$ Correspondence: Nazish Bostan, nazishbostan@comsats.edu.pk

The authors apologize for this error and state that this does not change the scientific conclusions of the article in any way.

Copyright (c) 2020 Sadiq and Bostan. This is an open-access article distributed under the terms of the Creative Commons Attribution License (CC BY). The use, distribution or reproduction in other forums is permitted, provided the original author(s) and the copyright owner(s) are credited and that the original publication in this journal is cited, in accordance with accepted academic practice. No use, distribution or reproduction is permitted which does not comply with these terms. 